\title{
History of Education in the News The Legacy of Slavery, Racism, and Contemporary Black Activism on Campus
}

\author{
Fames D. Anderson and Christopher M. Span
}

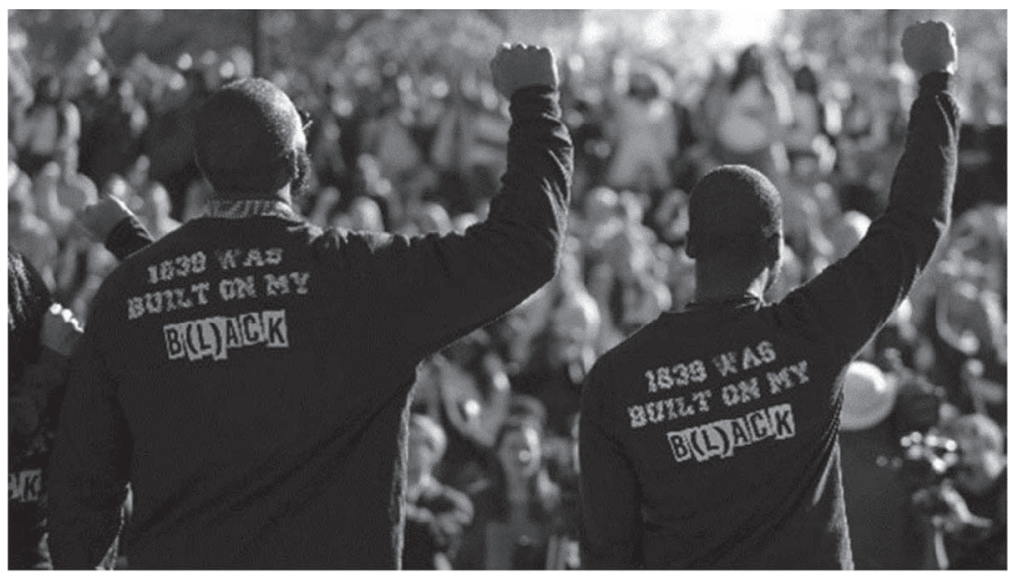

Members of Concerned Student 1950 protesting for racial equality at the University of Missouri in November 2015 (AP Photo/feff Roberson Photographer).

The History of Education Quarterly editorial team is planning to integrate a new feature, "History of Education in the Newws," into periodic issues of the journal. Our idea is to highlight relevant historical scholarship on a topic that has contemporary public resonance. Our first piece in this new vein engages the current uptick of interest in the links between slavery and bigher education. Recent scholarship and popular press accounts have documented how many eastern colleges and universities benefited from enslaved AfricanAmerican labor.

We asked Professors Fames D. Anderson and Christopher M. Span of the University of Illinois at Urbana-Champaign to take up this issue and reflect on how a deep knowledge of history informs recent activism on college and university campuses, particularly activism focused on forcing institutions to reckon with their histories and become antiracist spaces.

\footnotetext{
James D. Anderson is Head and Gutgsell Professor of Education Policy, Organization and Leadership at the College of Education, University of Illinois at Urbana-Champaign. Christopher M. Span is associate dean for Academic Programs at Education Administration, University of Illinois at Urbana-Champaign.
} 
As the late Maya Angelou stated so profoundly, "History, despite its wrenching pain, cannot be unlived, and if faced with courage, need not be lived again."1 Put another way by the late historian Eugene Genovese, it is never certain which lessons can be drawn from the past to inform the future, "Except perhaps one: Until a people can and will face its own past, it has no future." ${ }^{2}$ This essay explores the historical persistence of attitudes toward the sanctity of black life and its resulting impact on contemporary activism as expressed in social movements such as Black Lives Matter. While many Americans look for present-day arguments for or against Black Lives Matter, answers to understanding the origins of the primary motives for this movement are rooted in the past. We illustrate how the demands of contemporary student activists force their campuses to face their pasts, acknowledge the role of slavery and racism in their creation and success, and rectify their wrongs. In short, these activists aspire to have their universities become the first of many communities to unconditionally value everyone equally and make clear that white lives do not matter more than any other.

Americans have always had great difficulty facing their past squarely, especially around issues of genocide, slavery, and racism. It is common to view slavery as the distant past with no relevance to the present, while at the same time viewing other events that developed within the context of slavery (i.e., the Declaration of Independence, the War for Independence, the formation of the United States, and the ratification of the Constitution) as extremely relevant to the present and the future. The perpetual ritual of sanitizing the "wrenching pain" from our history renders us incapable of comprehending and understanding the political and cultural legacy of American slavery or the social movements that aim to overcome its continuing effects. In an article on the political legacy of American slavery, authors Avidit Acharya, Matthew Blackwell, and Maya Sen show that contemporary differences in political attitudes in the American South, in part, trace their origins to slavery's presence more than 150 years ago. "Drawing on a sample of more than 40,000 Southern whites and historical census records," Acharya, Blackwell, and Sen demonstrate "that whites who currently live in counties that had high concentrations of slaves in 1860 are today, on average, more conservative and express colder feelings toward African Americans than whites who live elsewhere in the South." 3 These

${ }^{1}$ Maya Angelou, Presidential Inaugural Poem, January 20, 1993, http://poetry. eserver.org/Angelou.html.

${ }^{2}$ Eugene D. Genovese, "The Nat Turner Case," New York Review of Books 11, no. 4 (September 12, 1968): 37.

${ }^{3}$ Avidit Acharya, Matthew Blackwell, and Maya Sen, "The Political Legacy of American Slavery," Fournal of Politics 78, no. 3 (July 2016), 621. 
authors make the simple, yet profound, point that racist norms and institutional arrangements to subordinate and control African Americans have been passed down locally across generations. Their research and findings illustrate a willingness to squarely face a past that most Americans prefer to disremember.

Nowhere is this historical amnesia more evident than in the contemporary reaction to black activism that is commonly known as the Black Lives Matter movement. A common response to Black Lives Matter is to assert that "all lives matter," and thus the focus on black lives, as some would have it, is inherently racist. This position assumes that historically black lives have mattered in the same manner as all other lives, including the lives of white Americans. In view of 250 years of slavery followed by 100 years of Jim Crow in southern states and patterns of pervasive racism in northern states, it would indeed be a remarkable result if slavery and racism failed to have a profound impact on the sanctity of black life. To the contrary, the historical record is replete with evidence of how black lives have not mattered.

Black life ceased to matter with the onset of the North Atlantic slave trade. This was poignantly portrayed in a 60 Minutes episode entitled "The Slave Ship," a story about the quest for the remains of a shipwreck (the São José Paquete d'Africa) that sank off the coast of Cape Town, South Africa, in $1794 .{ }^{4}$ It is the first time that the wreckage of a slaving ship that went down with slaves aboard has been recovered, along with a document detailing the rescue of the crew and half of the enslaved Africans. The document, which is in Portuguese and paraphrases the inquest testimony of the ship's captain, Manuel João, reminds us of the way in which regard for black lives had been reduced to livestock being transported as cargo. Captain João reported that he was able to save the men (meaning white men) but could save only half of the cargo (meaning black people). The distinction between people and cargo underscores the point that black lives did not matter except as valuable cargo to be sold. This attitude toward black bodies developed within a slave trade that lasted nearly 500 years and that made it virtually impossible to trade and sell people while maintaining a sense of dignity toward the sanctity of their lives.

The devaluation of black lives continued with each passing year of slavery, and, following the end of slavery in America, the disregard for black lives was passed on from one generation to the next. This fact is replete in every aspect of American life and culture and has been in plain sight even as we turned a blind eye to its significance. For generations, Americans read The Adventures of Huckleberry Finn while

${ }^{4} 60$ Minutes, "The Slave Ship," November 1, 2015, http://www.cbsnews.com/ news/the-slave-ship-60-minutes. 
ignoring Mark Twain's illustrations of how black lives didn't matter. When Huck, pretending to be Tom, tries to explain why he had been delayed, he explains that the steamboat engine was damaged when a cylinder head blew up. Huck says to Aunt Sally:

Huck: It warn't the grounding-that didn't keep us back but a little. We blowed out a cylinder-head.

Aunt Sally: Good gracious! Anybody hurt?

Huck: No'm. Killed a nigger.

Aunt Sally: Well, it's lucky; because sometimes people do get hurt. ${ }^{5}$

Clearly, the fact that a black man was killed did not factor into Aunt Sally's conception of "people." In 1884, Mark Twain used the fictional Aunt Sally, and the society in which she lived, to underscore the reality that the death of a black man was widely regarded among whites as unimportant. Indeed, Aunt Sally captures the attitude that Black Lives Matter seeks to change: the deep-seated habit of regarding the sanctity of black lives differently than that of white lives.

Both the disregard for the sanctity of black lives as well as the struggle to make black lives matter are products of slavery's past and have a detectable effect on present-day black activism. Hence, the answer to the question as to where we should begin in accounting for the rise of the Black Lives Matter movement lies in our past. It does not begin with the tragic deaths of Trayvon Martin, Michael Brown, Tamir Rice, or Sandra Bland, even as their deaths are part and parcel of the long-standing disregard for the sanctity of black lives. We must begin the accounting for the Black Lives Matter movement at the onset of the massive North Atlantic slave trade that made it impossible to treat black lives as people when their primary value to the New World was as cargo to be captured, bought, and sold like livestock. We should not be surprised at the emergence of a Joseph generation that knows not Pharaoh's generation and does not share historically conditioned sensibilities regarding the sanctity of black lives. What they feel and believe has been in the making for centuries and they will not stand for its continuance.

The recent black protest movements and activism, particularly on college campuses, illustrate this growing discontent. Within the past two years, black students at over eighty colleges and universities, from Harvard, Yale, Duke, and Occidental, to the University of Michigan and the University of Missouri, have submitted formal demands that their universities acknowledge their histories and change their practices, policies, and treatment of all people from underrepresented backgrounds,

${ }^{5}$ Mark Twain, The Adventures of Huckleberry Finn (New York: Harper and Brothers, 1912), 306-7. 
but particularly African-American students. ${ }^{6}$ The persistent overt acts of racism on their campuses, and the silence, resistance, and failure of university administrators, faculty, students, and alums to acknowledge and address these harms, reinforce the refrain that black lives are not valued as much as white lives. The devaluing, disregard, indifference, and mistreatment of black lives compared to white lives, and the lack of any meaningful response to remedy these problems, is what theologian and scholar Eddie S. Glaude Jr. has come to define as the "value gap." "No matter our stated principles or how much progress we think we've made," Glaude states, "white people are valued more than others in this country, and that fact continues to shape the life chances of millions of Americans." He concludes, "The value gap is in our national DNA."7 It continues to justify slavery, segregation, racism, and discrimination. It affords and denies opportunities. It determines who is protected and harmed. It determines who receives the benefit of the doubt or the "deficit of the doubt." It defines who is qualified, worthy, and deserving. The only way the value gap can be closed and dismantled is when whites show and express an appreciation and value for the lives of others as much as they do their own. It is arguably the last lingering vestige of slavery's past-a vestige that continues to haunt us to the present day.

Two of the more recent and notable Black Lives Matter protests to challenge this value gap occurred at Yale and at the University of Missouri at Columbia. The administrative responses to this activism are telling and mirror the title of the Charles Dickens classic $A$ Tale of Two Cities. The timeline for black activism at the University of Missouri tentatively began in November 2014 after the nonindictment of a Ferguson, Missouri, police officer who shot and killed unarmed black teenager Michael Brown three months earlier. It took center stage at the start of the fall 2015 semester when the student government president, Payton Head, posted on Facebook "his frustration with bigotry, anti-homosexual and anti-transgender attitudes at the school after people riding in the back of a pickup truck screamed racial slurs at him." 9 Missouri chancellor R. Bowen Loftin investigated the incident and immediately issued a statement deploring any act of discrimination, but student protesters felt the university's response was halfhearted and

\footnotetext{
${ }^{6}$ For the listing of universities and student demands, see http://www.thedemands. org.

${ }^{7}$ Eddie S. Glaude Jr., Democracy in Black: How Race Still Enslaves the American Soul (New York: Crown Publishers, 2016), 31.

${ }^{8}$ Jeff Cook, "Why I Am a Racist," Huffington Post, July 15, 2016, http://www. huffingtonpost.com/entry/why-im-a-racist_us_57893b9ee4b0e7c873500382.

"Michael Pearson, "A Timeline of the University of Missouri Protests," CNN, November 10, 2015, http://www.cnn.com/2015/11/09/us/missouri-protest-timeline/.
} 
more was needed to ensure the well-being and safety of everyone on campus.

Then, in early October, "a drunken white student disrupts an African American student group preparing for homecoming activities and uses a racial slur when asked to leave." 10 The next day, Chancellor Loftin issued another statement, again denounced the incident, and said "racism is clearly alive at Mizzou" and that "every member of our community must help us change our culture." 11 He instituted a policy - to begin at the start of the next academic year-that required all students and faculty to complete diversity and inclusion training. Two days later, black student protesters blocked the university president's car at the homecoming parade to voice their concerns. In an effort to get around the protesters, the car "taps a protester," further inflaming the situation. Ten days later, on October 20, "the student group Concerned Student 1950-named for the year African Americans were first admitted to the university-issue[d] a list of demands." 12 The administration did not respond immediately. Four days later, someone on campus used "feces to draw a swastika on the wall of a residence hall. A similar incident occurred in April, but with ashes."13 Two days later, after a private meeting with Concerned Student 1950, President Tim Wolfe refused to agree to all of their demands, one of which asked him and the chancellor to resign. In early November, one black student protester launched a hunger strike until all demands were met. A week later, more than sixty black football players "announce they won't practice or play until Wolfe is removed." 14 The athletics department, head football coach, and many white teammates announced their support of the players who stood in protest. One day later, November 9, approximately one year after the nonindictment of the Ferguson police officer, the University of Missouri system's administration said that President Wolfe and Chancellor Loftin had "undeniably failed us," and both immediately resigned thereafter.

Four days after the University of Missouri president was forced to resign, protest arose at Yale. Empowered by the mobilization, activism, and success at Missouri, protesters submitted a list of demands to Yale president Peter Salovey. The demands read:

Next Yale, an alliance of Yale students of color and our allies, have come together to demand that Peter Salovey and the Yale administration implement immediate and lasting policies that will reduce the intolerable

\footnotetext{
${ }^{10}$ Ibid.

${ }^{11}$ Ibid.

${ }^{12}$ Ibid.

${ }^{13}$ Ibid.

${ }^{14}$ Ibid.
} 
racism that students of color experience on campus every day ... Because the administration has been unwilling to promptly address institutional and interpersonal racism at Yale, Next Yale has spent hours organizing, at great expense to our health and grades, to fight for a university at which we feel safe-a university that we would feel happy sending our younger siblings and eventual children to attend ... In the spirit of the nationwide student mobilization demanding racial equality on campus-particularly at University of Missouri, Virginia Commonwealth University, and Ithaca College-Next Yale intends to hold Yale accountable to its students of color in the public eye. ${ }^{15}$

The response to the activism at Yale differed significantly from Missouri. University president Salovey immediately responded to their concerns, announcing that over the next five years Yale would invest more than $\$ 50$ million in initiatives to promote cultural awareness and inclusion, increase faculty diversity, and construct an academic center to "build a more inclusive Yale" and "reaffirm and reinforce [their] commitment to a campus where hatred and discrimination have no place."16

Amid this activism for access, inclusion, recognition, and equal consideration, one thing was certain: lessons from the past were being drawn upon to question the current and future considerations of these institutions of higher learning. On both sides of the discord, history mattered. Black student activists drew upon the past to explain their current conditions and demands, and administrators were forced to confront institutional and societal wrongs that many hoped would be disremembered, ignored, or simply forgiven. Sharp images stood out during these exchanges. At Missouri, black activists named their student group after the year the university admitted nine black students and became fully integrated. They wore T-shirts that read " 1839 was built on my B(l)ack," in reference to the role free and unfree blacks played in the construction and daily maintenance of the university since its founding in 1839. Yale activists insisted campus officials change the name of Calhoun College-a residential hall named in honor of alumnus and unapologetic defender of slavery John C. Calhoun. This was not a new demand. For decades, residents of the college and protesters demanded the building be renamed and that the stained glass windowpanes and iconography depicting the life of Calhoun as a prominent slaveholder

15 "Next Yale Demands for Administration," November 18, 2015, https://www. thefire.org/next-yale-demands-for-the-administration/.

${ }^{16}$ Isaac Stanley-Becker, "Yale's president responds to protesters' demands, announces new initiatives to ease racial tension," Washington Post, November 18, 2015, https://www.washingtonpost.com/news/grade-point/wp/2015/11/18/yales-presidentresponds-to-protesters-demands-announces-new-initiatives-to-ease-racial-tension. 
and enslaved blacks as cotton pickers be removed or replaced. ${ }^{17}$ Activists at Missouri and Yale illuminated the troubled history of slavery and racism at their universities, and the disremembering and unresponsiveness of generations of university leaders, faculty, students, and alum who dismissed or disregarded the intergenerational concerns of the black men and women who enhanced the profile and experiences of these campuses.

The timing of historian Craig Steven Wilder's account of the central role slavery and racism played in the building and shaping of America's first colleges and universities coincided with the protests roiling college campuses. As Wilder records in Ebony and Ivy, "Human slavery was the precondition for the rise of higher education in the Americas." ${ }^{18}$ Virtually every institution of higher education founded prior to the abolition of slavery was built and maintained, in some form, by the labor of free and enslaved blacks. Blacks were on college campuses, not as students, but as cheap sources of labor that both directly and vicariously taught whites enrolled and working in these spaces that blacks were inferior and subordinate and they were superior and leaders. Wilder demonstrates that for nearly two centuries universities valued black lives only to the extent that they could benefit from their presence. He details how curricula was developed and taught that "scientifically" race was immutable and biologically determined, that whites were superior, and that the expansion of Western civilization to every corner of the world was necessary, just, and beneficial. With each passing generation, graduates from these institutions of higher learning became the next assembly of elected officials, judiciaries, professors, theologians, educators, and businessmen to nurture morals and practices and to sanction ideologies, policies, laws, and institutions that justified slavery and racism, and exacerbated the human value gap between blacks and whites.

Wilder was not alone, however. The New York Times reported that "since 2003, when Ruth Simmons, then the president of Brown University, announced a headline-grabbing initiative to investigate that university's ties to slavery, scholars at William and Mary, Harvard, Emory, the University of Maryland, the University of North Carolina at Chapel Hill and elsewhere have completed their own studies." ${ }^{19}$ These

${ }^{17}$ Ed Stannard, "Renaming Calhoun College still possible as Yale forms committee after outcry," New Haven Register, August 1, 2016, http://www.nhregister.com/generalnews/20160801/renaming-calhoun-college-still-possible-as-yale-forms-committeeafter-outcry.

${ }^{18}$ Craig Steven Wilder, Ebony and Ivy: Race, Slavery, and the Troubled History of America's Universities (New York: Bloomsbury Press, 2013), 114.

${ }^{19}$ Jennifer Schuessler, "Dirty Antebellum Secrets in Ivory Towers: 'Ebony and Ivy,' About How Slavery Helped Universities Grow," New York Times, October 18, 
investigations substantiate the centrality slavery and racism had in the development and growth of their universities. The recent discovery that Georgetown University sold 272 enslaved blacks in 1838 to keep the institution afloat raises an important question as to whether these institutions of higher learning have any obligation and accountability to the descendants of those who were held in bondage or sold away from their families to save or advance the mission of universities that blacks, in mass, could not attend until well into the twentieth century. ${ }^{20}$

In the wake of these findings, Georgetown took the initiative to begin the healing process. It established a working group to identify ways the university could acknowledge and make amends for this troubled history. Genealogists were hired to work alongside Georgetown alums, faculty, and students to trace and find the descendants of the 272 enslaved blacks sold to keep the university solvent. It is "weighing whether the university should apologize for profiting from slave labor, create a memorial to those enslaved and provide scholarships for their descendants." As Adam Rothman, a historian at Georgetown and member of this working group, correctly states, "It's hard to know what could possibly reconcile a history like this ... the university itself owes its existence to this history." 21 Important questions need answers in light of these explorations and findings. What can be done to make amends? What must society, communities, institutions, and individuals do to move beyond this troubled past to ensure it does not continue to fester and fracture into a troubled future? To come to the point, where do we go from here?

The collective knowledge and histories produced and recorded on the impact slavery and racism have had, not merely on the rise of American colleges and universities, but on the dehumanization of blacks for the benefit of whites, is essential to understanding and addressing the value gap that still plagues our society. These histories expand our understanding of how ingrained the impacts of slavery and race are. As historian Eric Foner reasons, "It is hardly a secret that slavery is deeply embedded in our nation's history. But many Americans still see it as essentially a footnote, an exception to the dominant narrative of the expansion of liberty on this continent." ${ }^{22}$ In order for our nation to

2013, http://www.nytimes.com/2013/10/19/books/ebony-and-ivy-about-how-slaveryhelped-universities-grow.html.

${ }^{20}$ Rachel L. Swarns, "272 Slaves Were Sold to Save Georgetown. What Does It Owe Their Descendants?” New York Times, April 16, 2016, http://www.nytimes. com/2016/04/17/us/georgetown-university-search-for-slave-descendants.html.

${ }^{21}$ Ibid.

${ }^{22}$ Eric Foner, "A Brutal Process: 'The Half Has Never Been Told,' by Edward E. Baptist," New York Times, October 3, 2014, http://www.nytimes.com/2014/10/05/ books/review/the-half-has-never-been-told-by-edward-e-baptist.html. 
truly begin the healing process, we must reflect upon and acknowledge our past and better understand the society we have inherited. Then, and only then, will we be able to take the necessary steps to make amends and hopefully get to a point of meaningful and momentous reconciliation.

That is what this current generation of activists demands, and they seem prepared to accept nothing less. Black activists protesting across America's colleges and universities have relied on these recently uncovered histories and this process of self-reflection to further articulate their concerns and demands. They connect these histories to their own experiences in an effort to impact meaningful change for themselves and future students on their campuses. They demand their campuses proactively speak out against racism and discrimination, adapt their culture and practices to challenge these vices, and implement plans and policies to protect, include, develop, and value them. Their activism underscores a collective and long-standing demand made by every generation of blacks before them who sought to be recognized as persons of equal value and consideration, and to be regarded as something more than a commodity for another person's profit, consumption, benefit, fear, or imagination. "These activists force us, whether we agree with them or not," as Glaude thoughtfully penned, "to think about how we currently live our lives. In short, they shed light on our racial habits and create the conditions, however fleeting, for us to change them." 23

These contemporary activists call us to action; they ask us to strive alongside them in the hopes of upending the enduring ill effects of slavery and racism and to help them establish a social order where black lives not only matter, but are unequivocally valued. On our campuses, they expect us to develop guidelines and action plans that define and confront racial harassment and protect them from its harms. Truth be told, we should have already laid this foundation; they should never have had to ask. Fundamentally, they expect us to live up to the aspiration we've championed for generations (and they have come of age believing as truth) that America, in general, and our universities, more specifically, are one of the few places in the world where everyone is valued and given equal consideration. Their lived experiences conflict in important ways with this aspiration and encapsulate the growing frustrations and angst these activists feel. Just as universities expect students to learn, succeed, develop, and become excellent ambassadors of their institutions and creed, students protesting for change expect their campuses to close the gap between their professed values and the ones they live. They want their campuses to acknowledge and face their past with courage, even

${ }^{23}$ Glaude, Democracy in Black, 184. 
if it is a wrenching pain, as Maya Angelou expressed, so that it need not be lived again.

We cannot undo our past, but we can learn from it; examples abound prove this truth. History provides a lens and medium for us to revisit who we were, what we did, and how our thoughts and actions make us who we are today. History affords opportunities to address failings and start anew. If the ideals of society and our profession impress upon us to teach the general public to appreciate diversity and inclusion, to be self-reflective and mindful of others, and to enhance our strengths and remedy our limitations, then it is imperative we have the moral compass and courage to learn from our pasts, amend their shortcomings, and develop and implement the practices, policies, and innovations necessary to produce the outcomes, opportunities, and reconciliation that this current generation and future generations of Americans rightfully deserve. 